\title{
Holocene molluscan assemblages in the Magellan region*
}

\author{
SANDRA GORDILLO \\ Centro Austral de Investigaciones Científicas (CADIC, CONICET) C.C. 92, 9410 Ushuaia, Tierra del Fuego, Argentina. \\ Present address: Cátedra de Estratigrafía y Geología Histórica, Universidad Nacional de Córdoba, Avda. Vélez Sárfield, \\ 5000 Córdoba, Argentina.
}

\begin{abstract}
SUMMARY: In the Magellan region, much of the shoreline of the Beagle Channel coast $\left(54^{\circ} 53^{\prime} \mathrm{S} ; 67^{\circ}-68^{\circ} \mathrm{W}\right)$ is bordered by Holocene raised beaches, which contain a large number of molluscs and other shelled taxa. The purpose of this work is to document the presence of various molluscan assemblages deposited with little or no postmortem transportation. An epifaunal Chlamys patagonica palaeocommunity (ca. 8,000 - 7,000 BP) and three infaunal (Tawera gayi, Ameghinomya antiqua - Hiatella solida and Ameghinomya antiqua - Ensis macha) palaeocommunities (ca. 4,400 - 4,000 BP) were recognized. All the assemblages studied represent shallow, subtidal, cold-temperate environments. Based on comparisons with modern benthic communities in this region, these associations show that no remarkable ecologic and climatic changes occurred during the period ca. 8,000 - 4,000 BP. Thus, an apparent stability of modern marine communities over a period of several thousand years is suggested.
\end{abstract}

Key words: Holocene, molluscan assemblages, Magellan region.

\begin{abstract}
RESUMEN: Asociaciones de moluscos del Holoceno en la Región de Magallanes. En la región de Magallanes, gran parte de la costa del Canal del Beagle $\left(54^{\circ} 53^{\prime} \mathrm{S} ; 67^{\circ}-68^{\circ} \mathrm{O}\right)$ está caracterizada por la presencia de playas elevadas del Holoceno, que contienen un gran número de moluscos y otros taxones. El objetivo de este trabajo es documentar la presencia de distintos tipos de asociaciones de moluscos depositadas sin previo transporte o escaso transporte postmortem. Se reconocieron una paleocomunidad epifaunal de Chlamys patagonica (ca. $8.000-7.000 \mathrm{AP}$ ) y tres paleocomunidades infaunales de Tawera gayi, Ameghinomya antiqua-Hiatella solida y Ameghinomya antiqua-Ensis macha (ca. 4.400 - 4.000 AP). Todas estas asociaciones representan ambientes marinos costeros templado-fríos. Al comparar las asociaciones estudiadas con las unidades equivalentes actuales no se han detectado cambios ecológicos y climáticos durante el período considerado ca. 8.000 - 4.000 AP, lo que sugiere un período de estabilidad de las comunidades de moluscos de varios miles de años.
\end{abstract}

Palabras clave: Holoceno, asociaciones de moluscos, región de Magallanes.

\section{INTRODUCTION}

Holocene marine molluscs are widely preserved in the geological record. Nevertheless, the majority of these fossil molluscan assemblages -closely associated with the offshore to beach gradientconsist of preburially transported assemblages

\footnotetext{
*Accepted February 15, 1999.
}

(allochthonous assemblages), which have little palaeoecological interest. This is not the case of the mollusc assemblages considered in this work, which have two characteristics used as tools for palaeoecological interpretations: (1) they were deposited in situ (autochthonous assemblages), or with little preburial transport (parautochthonous assemblages), and (2) the species are living taxa in the Magellan region. As used here, the term "sub- 
fossil" refers to animal remains of Holocene age, i.e. up to 10,000 years old.

The purpose of this work is to document the systematics of the subfossil species, the taphonomic evidence and the mollusc assemblage types. In addition, the trophic relationships and the ecological and palaeoecological characteristics of the species are discussed.

The Beagle Channel $\left(54^{\circ} 53^{\prime} \mathrm{S}, 67^{\circ}-68^{\circ} \mathrm{W}\right.$ ) is located in the Magellan region within the Fuegian Andes environment. Late Jurassic volcanic rocks (Lemaire Fm.; Borello, 1969) follow the potential Paleozoic-early Mesozoic basement (Lapataia Fm.; Borello, 1969). Cretaceous marine rocks overlay this formation (Yahgan Fm.; Kranck, 1932). Eocene continental beds (Slogget Fm.; Caminos, 1980) intruded by eruptive rocks (Quartino et al., 1989) represent the Tertiary. The stratigraphical scheme is completed with Quaternary sediments: Pleistocene glacial deposits and Holocene marine terraces. Holocene raised beaches border much of the shoreline of the Beagle Channel coast. During the Holocene, the palaeogeographic evolution of the Beagle Channel terraces system has been mainly controlled by glacioisostatic uplift and partly by neotectonic activity, notably by displacements on several minor faults (Rabassa et al., 1989; Gordillo et al., 1992).

According to Iturraspe et al., (1989) the Beagle Channel shows an average temperature at $2 \mathrm{~m}$ depth of $6.5^{\circ} \mathrm{C}$, with a maximum of $10^{\circ} \mathrm{C}$ (February) and a minimum of $3^{\circ} \mathrm{C}$ (August); and salinity varies from 27 to $31 \%$.

The localities considered in this work (Fig. 1) were selected on the basis of the features of the molluscan assemblages previously studied by

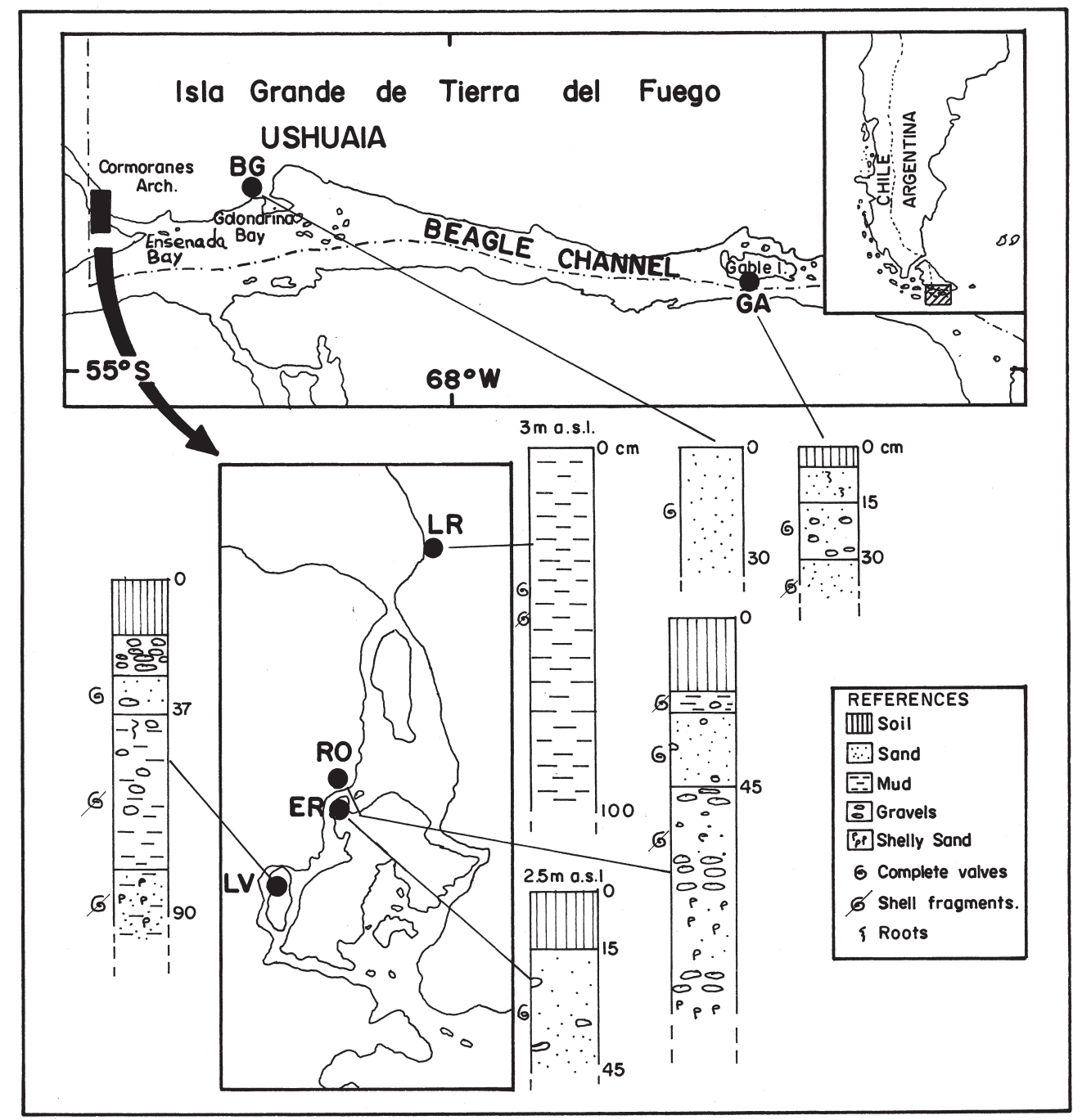

FIG. 1. - Map of the Beagle Channel showing sampling locations. LR: Lago Roca; RO: Río Ovando; ER: Entre Ríos; LV: Laguna Verde; BG: Bahía Golondrina and GA: Isla Gable. 
Gordillo (1993) and Gordillo et al. (1993). In the western sector, Figure 1 shows the Cormoranes Archipelago which includes the Lago Roca (LR), Río Ovando (RO), Entre Ríos (ER) and Laguna Verde (LV) sites. Low islands where Holocene deposits contain molluscs buried in situ cap this area. At present, this area is disconnected from the Beagle Channel and is occupied by fresh water. The exposed profile of the LR site is a greyish silty massive bed $3.0 \mathrm{~m}$ above sea level (a.s.l.) radiocarbon dated by Gordillo et al. (1993) at $7518+/-58$ BP (NZ \# 7730). Shells of the RO were dated by Rabassa et al. (1986) at 4425 +/-55 BP (SI \# 6735). The ER and the LV sites can be correlated, according to their elevation (near 2.5 - $3.0 \mathrm{~m}$ a.s.1.), with the Río Ovando site. In the central sector the existence of a profile with molluscs in life position close to the Golondrina bay (BG; Fig. 1), $5 \mathrm{~km}$ east of Ushuaia, must be mentioned. Finally, in the eastern sector, molluscs without signs of transportation near $3 \mathrm{~m}$ above m.s.l. were also found on Gable Island (IG; Fig. 1).

\section{MATERIAL AND METHODS}

Molluscs from each assemblage mentioned in Figure 1, i.e. LR, RO, ER, LV, BG and IG, were identified, counted and measured in size. Shell size range (SSR) of the main taxa, relative abundance of the articulated valves (AV) and orientation of the shells (life position or horizontal position) were calculated. Biodiversity of the preservable groups was also considered. The Shannon index $\left(\mathrm{H}^{\prime}\right)$ as an estimate of species richness was coupled with the Shannon evenness (E) as a measure of evenness and with the Simpson index (D) as a measure of dominance. Diversity was calculated separately for each assemblage. High values of the Shannon index indicate a combination of many species and an even distribution of the specimens over the species. In relation to evenness, values close to the maximum of 1 show uniform abundances of the taxa. Finally, as dominance increases diversity decreases (see equations in Magurran, 1988).

Complementary observations of modern benthic communities of the Beagle Channel were made in the intertidal zone at low-water mark in the sublittoral zone by means of SCUBA diving, and under laboratory conditions at the aquarium of the CADIC. Material was collected during March and October 1988.
TABLE 1. - List of the total fauna of molluscs collected in the studied area.

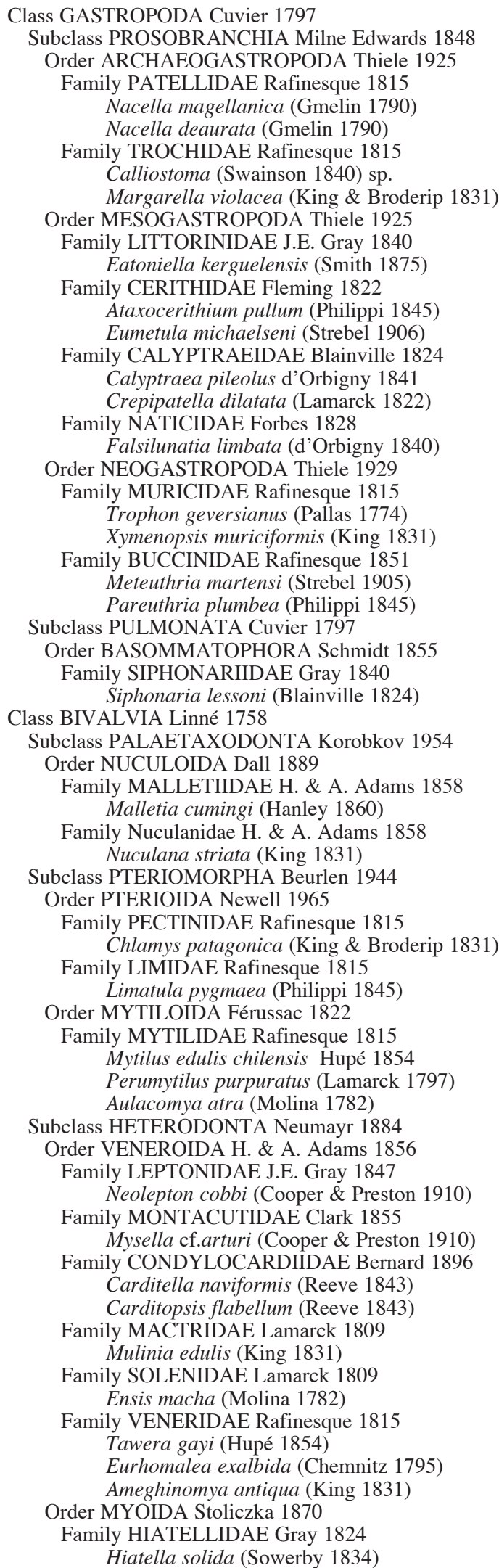


TABLE 2. -- Characteristics of the six palaeocommunities identified here with regard to shell size range (SSR), relative abundance of articulated valves (AV), and orientation/ preburial transport .

\begin{tabular}{|c|c|c|c|}
\hline $\begin{array}{l}\text { LOCALITIES and } \\
\text { DOMINANT SPECIES }\end{array}$ & $\begin{array}{l}\text { SSR } \\
(\mathrm{mm})\end{array}$ & $\begin{array}{l}\text { AV } \\
(\%)\end{array}$ & $\begin{array}{c}\text { ORIENTATION/ } \\
\text { PREBURIAL TRANSPORT }\end{array}$ \\
\hline \multicolumn{4}{|l|}{ 1. Lago Roca (LR) } \\
\hline $\begin{array}{l}\text { Chlamys patagonica } \\
\text { 2. Río Ovando (RO) }\end{array}$ & $07-80$ & 100 & horizontal position / low transport \\
\hline Tawera gayi & $12-38$ & 100 & life position / in situ \\
\hline Hiatella solida & $31-51$ & 100 & life position / in situ \\
\hline \multicolumn{4}{|l|}{ 3. Entre Ríos (ER) } \\
\hline Tawera gayi & $04-31$ & $0 *$ & horizontal position / low transport \\
\hline Hiatella solida & $32-46$ & $0^{*}$ & horizontal position / low transport \\
\hline \multicolumn{4}{|l|}{ 4. Laguna Verde (LV) } \\
\hline Ameghinomya antiqua & $59-71$ & 100 & life position / in situ \\
\hline Hiatella solida & $35-44$ & 100 & life position / in situ \\
\hline \multicolumn{4}{|l|}{ 5. Ba.Golondrina (BG) } \\
\hline Ameghinomya antiqua & $\mathrm{n} / \mathrm{c}$ & 100 & life position / in situ \\
\hline Ensis macha & $95-135$ & 100 & life position / in situ \\
\hline \multicolumn{4}{|l|}{ 6. Isla Gable (GA) } \\
\hline Tawera gayi & $12-31$ & $0 *$ & horizontal position / in situ \\
\hline
\end{tabular}

* ratio of opposite valves is near $1: 1$.

\section{RESULTS}

All of the gastropods and bivalves sampled as subfossils are listed in Table 1. Table 2 shows characteristics of the palaeocommunities identified here with regard to shell size range (SSR), relative abundance of articulated valves (AV), and orientation/ preburial transport. In addition, Table 3 shows the living and non-preservable organisms associated with shallow molluscs in the Beagle Channel. For the trophic analysis, the life habit and feeding type are also considered in the table.

Based on previous information in the literature (Castilla, 1985; Comoglio, pers. comm.; Gordillo, 1994, 1995; Gordillo and Isla, 1991; Humphrey et al., 1970; Ojeda and Santelices, 1984) and new observations, Figure 2 summarizes the probable trophic relationships of the subfossil molluscs from the Beagle Channel. Taking into account all the information, the following reconstruction of the Holocene palaeocommunities is proposed.

\section{The Chlamys patagonica palaeocommunity}

(Fig. 3A)

This is the most diverse assemblage recognized in the data set and is characterized by the dominance of Chlamys patagonica. This disturbed-neighborhood (parautochthonous) assemblage consists of shell deposits with evidence of minimal shell transport. Shell material comprises whole specimens that are well preserved and non-abraded. The long, fragile Chlamys shells suggest a quiet-water environ-
TABLE 3. - Living and non-preservable organisms associated with shallow-water molluscs in the Beagle Channel. EP: epifaunal; IN: infaunal; VAG: vagrant; PR: producer; SF: suspension feeder; CAR: carnivorous; DF: deposit feeder.

\begin{tabular}{lcc}
\hline Taxa & Life habit & Trophic group \\
\hline Macrocystis pyrifera & EP & PR \\
Lessonia sp. & EP & PR \\
Ulva sp. & EP & PR \\
Cladophora sp. & EP & PR \\
Iridaea sp. & EP & PR \\
Nothogenia sp. & EP & PR \\
unidentified sponges & EP & SF \\
unidentified anemones & EP & CAR \\
spirorbid annelids & EP & SF \\
serpulid annelids & IN & SF \\
Lithodes santolla & VAG & CAR \\
Paralomis granulosa & VAG & CAR \\
Halicarcinus planatus & VAG & CAR \\
unidentified spp. & EP & SF \\
Cosmasterias lurida & VAG & CAR \\
Patiria sp. & VAG & CAR \\
Pseudechinus magellanicus & VAG & DF \\
Austrolycus depressiceps & VAG & CAR \\
Patagonotothen tesselata & VAG & CAR \\
& & \\
\hline
\end{tabular}

ment. Articulated valves indicate minimal current transport.

Besides the main taxa considered in Figure 3A, other molluscs such as Ameghinomya antiqua, Tawera gayi and Nuculana striata appeared as single valves and were interpreted as part of the shelly covered substratum. No attempt was made to count specimens less than $5 \mathrm{~mm}$-such as micromolluscs, juvenile molluscs, foraminifers and ostracods- because they are considered part of the sediment fraction. Barnacles and young specimens of the brachiopod Magellania venosa were not 
THIRD LEVEL CONSUMERS

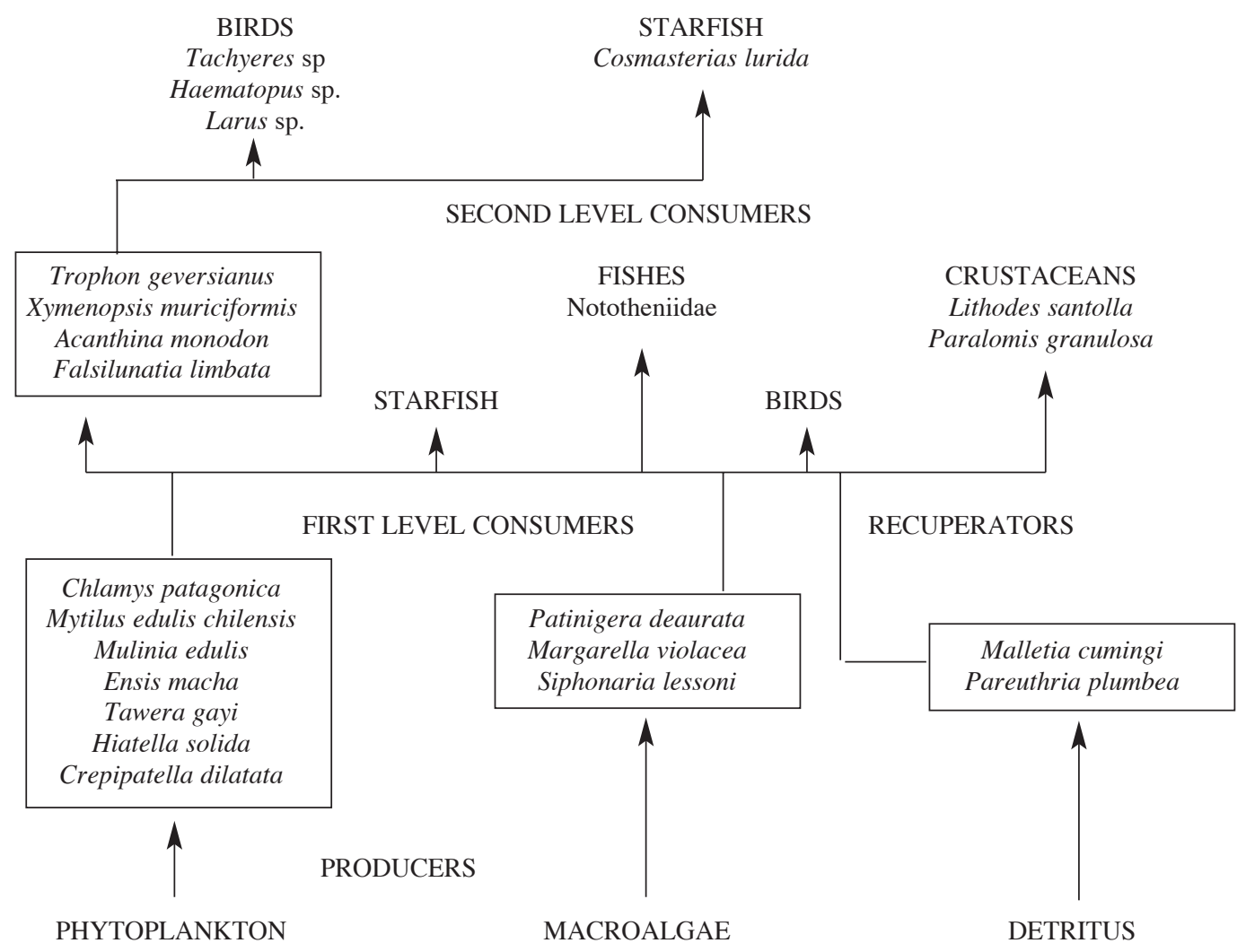

FIG. 2. - Probable trophic relationships of the subfossil molluscs from the Beagle Channel. Molluscs are listed within rectangles.

counted because they are considered as forming part of the epibiontic community of bivalves. Living specimens of Chlamys patagonica from Bahía Ushuaia have valves covered by epibionts, which mainly consist of non-preservable organisms. These include limpets, barnacles, bryozoans, encrusting sponges and the agglutinated tubes of spirorbid annelids. Only limpets and barnacles are preserved as subfossils. These groups form dense clusters on the Chlamys left valve (upper surface). The dominant species Chlamys patagonica, barnacles and other bivalves are epifaunal suspension feeders. Other trophic types less represented include grazers, predators and detritus feeders. The highest biodiversity value (2.12) corresponds to this epifaunal palaeocommunity. The lower dominance of this palaeocommunity is indicated by the lowest value of 0.24 . A great similarity between this palaeocommunity and modern ones described by other authors (McCammon and Buchsbaum, 1968; Valladares and Andrade, 1990; Privitera, 1992) for the Magellan Straits (Tierra del Fuego) is apparent.

\section{The Tawera gayi palaeocommunity}

(Fig. 3B)

This association is composed of several species of semi-infaunal and infaunal bivalves and gastropods. Other common groups are epifaunal brachiopods and barnacles. The Tawera gayi association was described from the Río Ovando (RO; $n=98$ ), Isla Entre Ríos (ER; $n=99$ ) and Isla Gable (GA; $n=42)$ sites. Figure 3 B shows a reconstruction of the Tawera gayi palaeocommunity at the Río Ovando site. Other groups are micromolluscs (Limatula pygmaea; Carditella naviformis; Carditopsis flabellum), foraminifers and ostracods, but they were not counted (for the same reasons as described above). Ophiuroids and echinoids are represented commonly as isolated ossicles and spicules. Finally, barnacles -as epibionts of bivalves- are also a main component of the mollusc assemblages. $T a$ wera gayi and Hiatella solida are the dominant species at the different localities considered, although there are some differences in the subdominant species. The small clam Tawera gayi is a semi- 
infaunal suspension feeder, which lives partially buried within the sandy subtidal in depths of 2-10 m. In contrast, Hiatella solida is known to have great variability in its life habits and habitats (it also lives in the epifaunal palaeocommunity). In the Beagle Channel, it lives attached to pebbles, shells and kelp, or partially buried - as a free form - on sandy and finer sediments (Gordillo, 1995). The presence of Tawera gayi at the Cormoranes Archipelago suggests shallow subtidal conditions and depths of 1-10 $\mathrm{m}$ for the assemblages. Due to the presence of Siphonaria lessoni, the GA locality may be regarded as a very shallow water environment. The presence of fragments of mytilids at the ER site suggests some physical mixing of faunas from rocky envi- ronments. From a trophic viewpoint, suspension feeders, grazers and carnivores make up 80-90\%, 5$10 \%$ and $1-5 \%$ of the individuals in the Tawera gayi associations respectively. Near-normal marine salinity is indicated by the presence of venerid bivalves. At present times, the Tawera gayi association is a typical shallow-water community of sandy sediments in the Beagle Channel.

\section{The Ameghinomya antiqua-Hiatella solida palaeocommunity (Fig. 3C)}

This association is decribed for the Laguna Verde (LV; $n=32$ ) site. Similar to other venerids, Ameghinomya antiqua cannot tolerate brackish and estuar-
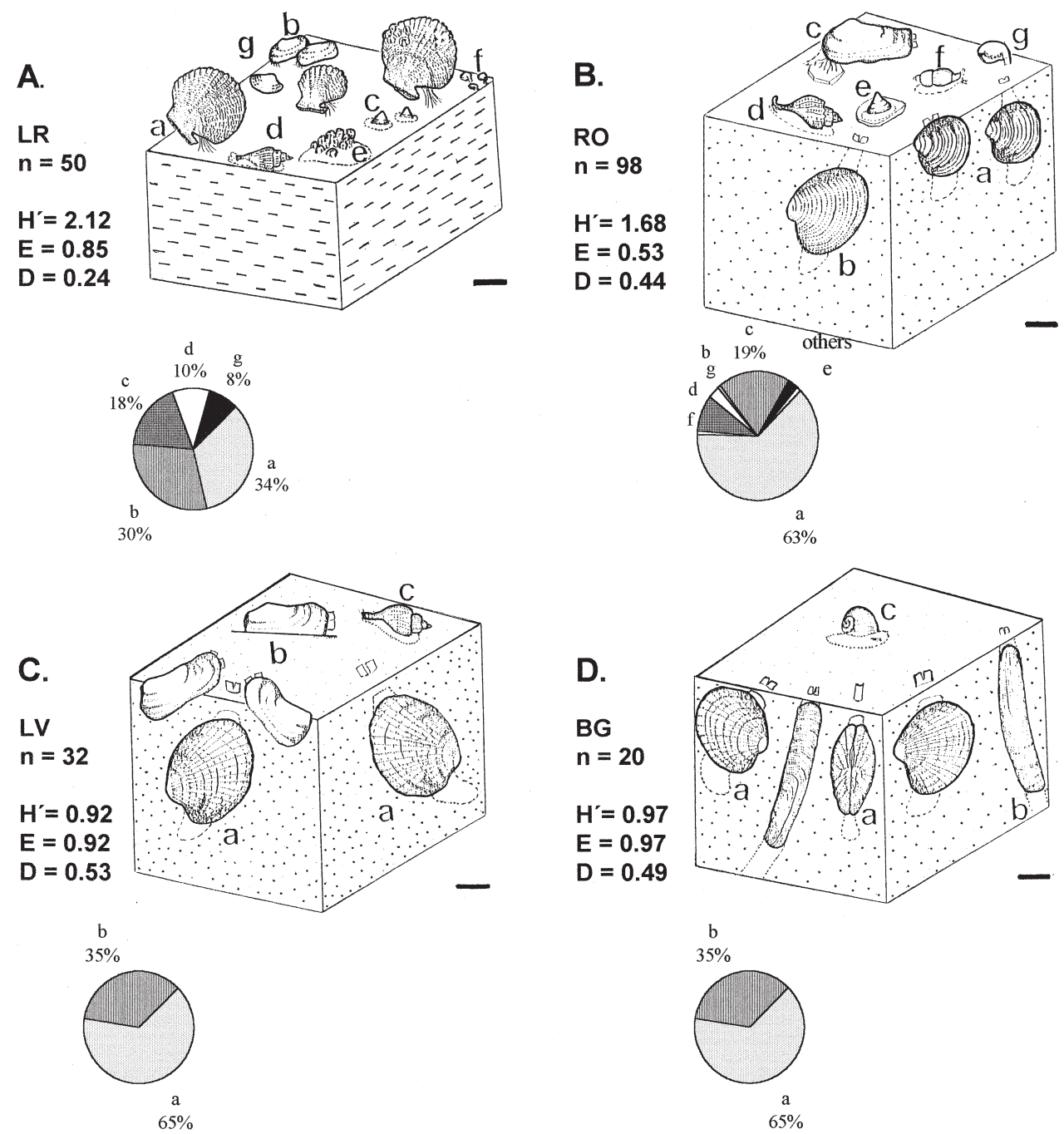

FIG. 3. - Frequency of occurrence of the main taxa; biodiversity indices and reconstruction of the Holocene molluscan palaeocommunities in the studied area. (A). Chlamys patagonica palaeocommunity. a: C.patagonica; b: Hiatella solida; c: Calyptraea pileolus; d: Trophon geversianus; e: barnacles and f: Magellania venosa (brachiopod). (B). Tawera gayi palaeocommunity. a: T. gayi; b: Eurhomalea exalbida; c: Hiatella solida; d: Trophon geversianus; e: Calyptraea pileolus; f: Pareuthria plumbea and g: Magellania venosa. (C). Ameghinomya antiqua-Hiatella solida palaeocommunity. a: A.antiqua; b: H. solida; c: Trophon geversianus. (D). Ameghinomya antiqua-Ensis macha palaeocommunity. a: A. antiqua; b: E. macha and c: F. limbata. See explanations of the diversity indices in the text. Scale 20 mm. 
ine environments, so this palaeocommunity also falls within the normal water salinity mentioned for this geographic area. It inhabits coarse sandy waters at depths between $2 \mathrm{~m}$ and $10 \mathrm{~m}$. The trophic structure of this community is marked by an abundance of infaunal suspension feeders. The existence of drilled shells in the sediment fraction and the presence of drilling gastropods (muricids and naticids) in benthic modern communities of the region suggests that drilling gastropods are also part of this palaeocommunity.

\section{The Ameghinomya antiqua-Ensis macha palaeocommunity (Fig. 3D)}

The Ameghinomya antiqua-Ensis macha association is decribed for the Bahía Golondrina (BG; $n=20)$ site. Differences in composition from the Ameghinomya antiqua-Hiatella solida association of the LV site may be due to a slightly deeper environment in this case, because E. macha lives in deeper subtidal water $(10 \mathrm{~m})$ within sandy substrata. Infaunal living communities that include Ameghinomya antiqua and Ensis macha were described by Urban (1994) from the Bay of Dichato at the Pacific $\left(36^{\circ} 32^{\prime} \mathrm{S}, 73^{\circ} 57^{\prime} \mathrm{W}\right)$. This author correlates the distribution pattern of six infaunal bivalves with that of the sediment grain sizes: i.e. at one station $(\mathrm{CM})$ with coarse sand as well as very fine sediments only Ameghinomya antiqua was present, whereas at another station $(\mathrm{PH})$ the sediments were finer and only Ensis macha and the bivalve Tagelus dombeii were found. Thus, in life, the two species inhabit different patches within the same environment, but as fossil (our data) the species coexist within the same substrata, showing that coexistence is partly related to their different adaptations to the grain size (horizontal zonation). Another element that controls the coexistence of these filter feeding species, which compete for space and food, is also considered by Urban (1994). This author concludes that different burrowing depths in the substratum (vertical zonation) reduce competition between the two species and permit coexistence in the same environment. Thus, this observation would be applicable to the association described here, since Ameghinomya antiqua is a shallow burrowing and Ensis macha a deep burrowing species. As seen above, the trophic structure of this community is also marked by an abundance of infaunal suspension feeders. No other trophic groups were found, but Ensis macha can be consid- ered ecologically equivalent to Ensis directus from the Northern Hemisphere, described by Frey et al. (1986). These authors mentioned that $E$. directus is a prey of the naticid Polinices duplicatus, which captures its prey by attacking its foot rather than by drilling through the shell. The gastropod P. duplicatus would be ecologically equivalent to Falsilunatia limbata from the Beagle Channel. Consequently, it is possible that the naticids prey on E. macha without evidence of drilling. Evenness in these Ameghinomya antiqua palaeocommunities reaches the highest values and hence the diversity is less than that of the other palaeocommunities.

\section{CONCLUSIONS}

The molluscan assemblages indicate that little or no postmortem transportation has taken place, so they represent accurately the distribution of living populations from which they were derived. All these associations suggest shallow, subtidal, cold-temperate environments. An epifaunal Chlamys patagonica palaeocommunity (ca. 8,000-7,000 BP) and three infaunal (Tawera gayi; Ameghinomya antiquaHiatella solida; and Ameghinomya antiqua-Ensis macha) palaeocommunities (ca. 4,400-4,000 BP) are recognized. In spite of the different relative ages of these palaeocommunities, and based on the knowledge that a warmer intermediate period took place ca. 6,000-4,500 BP, coinciding with the highest sea level, they must have developed in two similar relatively cool periods (i.e. before and after the Hypsithermal).

The Chlamys patagonica palaeocommunity is the most diverse assemblage recognized, and is also characterized by the presence of preservable and non-preservable epibionts including limpets, barnacles, bryzoans, encrusting sponges and spirorbid annelids. On the other hand, infaunal palaeocommunities exhibited less diverse values, with the minimum diversity corresponding to the Ameghinomya antiqua-Ensis macha palaeocommunity.

Reconstruction of trophic structure based primarily on characteristics of living taxa shows that the Holocene benthic palaeocommunities were composed of infaunal and epifaunal-suspension feeding bivalves, and a minor component of deposit feeders. Among gastropods there were detritus collectors, swallowers and carnivores. Predators of molluscs probably include starfish, crabs, drilling gastropods, nototheniid fish and birds. 
Finally, based on comparisons with modern benthic communities in this region, these associations show no evidence of dramatic ecologic and climatic changes during the period considered (ca. 8,000 $4,000 \mathrm{BP}$ ). After deglaciation, these faunas apparently occupied the new vacant niches, and minor climatic changes during this very brief period could not be enough to produce significant changes in the faunal composition of these wide temperate-cold distributed species. Thus, a postglacial succession of faunas is not evidenced from these data, suggesting an apparent stability of modern marine communities over a period of several thousand years.

\section{ACKNOWLEDGEMENTS}

Thanks are extended to Teresa Sánchez (Univ. Nac. Córdoba) who reviewed an early version of the manuscript and offered valuable suggestions; to the journal referees, W. Arntz (Alfred Wegener Institut for Polar and Marine Research) and J. A. Crame (British Antarctic Survey), and one anonymous referee; to Rafael Pastorino for his kind help in SCUBA diving; and to Miguel Isla and Sandra Molina for their aid in identification of some taxa. Research was supported by a grant from the Argentine National Research Council (CONICET) to Jorge Rabassa. This work was written while the author held a CONICET predoctoral fellowship.

\section{REFERENCES}

Borello, A.V. - 1969. Los geosinclinales de la Argentina. An. Direc. Nac. Geol. Min., 14: 1-188.

Caminos, R. - 1980. Cordillera Fueguina. In: J. C. Turner (ed.): Geología Regional Argentina. Academia Nacional de Ciencias 2: $1463-1499$.

Castilla, J. - 1985. Food webs and functional aspects of the kelp, Macrocystis pyrifera, community in the Beagle Channel, Chile. In: W.R. Siegfried, P.R. Condy and R.M. Laws (eds): Antarctic Nutrient Cycles and Food Webs, pp. 407-414. Springer Verlag, Berlin, Heidelberg

Frey, R.W., J.D. Howard and J.-S. Hong. - 1986. Naticid gas- tropods may kill solenid bivalves without boring: ichnologic and taphonomic consequences. Palaios, 1: 610-612.

Gordillo, S. - 1993. Las terrazas marinas holocenas de la región del Beagle (Tierra del Fuego) y su fauna asociada. Actas XII Congr. Geol. Argentino, 6: 34-39.

Gordillo, S. - 1994. Perforaciones en bivalvos subfósiles y actuales del Canal Beagle, Tierra del Fuego. Ameghiniana, 31: 177-185.

Gordillo, S. - 1995. Recent and living Hiatella solida (Mollusca: Bivalvia) from the Beagle Channel, southernmost South America. In: J. Rabassa and M. Salemme (eds): Quaternary of South America and Antarctic Peninsula, 9: 189-210. Balkema, Rotterdam.

Gordillo, S., G. Bujalesky, P.A. Pirazzoli, J.O. Rabassa and J.F. Saliege. -1992 . Holocene raised beaches along the northern coast of the Beagle Channel, Tierra del Fuego, Argentina. Palaeogeogr., Palaeoclimat., Palaeoecol., 99: 41-54.

Gordillo, S., A. Coronato and J. Rabassa. - 1993. Late Quaternary evolution of a subantarctic paleofjord, Tierra del Fuego. Quaternary Sci. Rev., 12: 889-897.

Gordillo, S. and M. Isla. - 1991. Moluscos hallados en el tubo digestivo de peces nototénidos del Canal Beagle, Tierra del Fuego. Comunicac. Soc. Malacol. Uruguay, 60-61: 245-256.

Humphrey, P., D. Bridge, P. Reynolds and R. Peterson. - 1970. Birds of Isla Grande (Tierra del Fuego). Smithsonian Institution, Washington D.C.

Iturraspe, R., R. Sottini, C. Schroeder and J. Escobar. - 1989. Hidrología y variables climáticas del Territorio de Tierra del Fuego. Contrib. Científ. CADIC, 7: 1-196.

Kranck, E.H. - 1932. Geological investigations in the Cordillera of Tierra del Fuego. Acta Geogr., 4: 1-231.

Magurran, A.E. - 1988. Ecological diversity and its measurement. Champman and Hall, New York.

McCammon, H. and R. Buchsbaum. - 1968. Size and shape variation of three recent brachiopods from the Strait of Magellan. Antarct. Res. Ser., 11, Biol. Antarct. Seas, 3: 215-225.

Ojeda, F.P. and B. Santelices. - 1984. Invertebrate communities in holdfasts of the kelp Macrocystis pyrifera from southern Chile. Mar. Ecol. Prog. Ser., 16: 65-73.

Privitera, S. - 1992. Popolamenti e tanatocenosi a molluschi dello Stretto di Magellano. Rapp. intermedio Univ. di Messina, pp. 112. Unpubl. rep.

Quartino, B., R.D. Acevedo and J. Scalabrini Ortiz. - 1989. Rocas eruptivas volcanógenas entre Monte Olivia y Paso Garibaldi, Tierra del Fuego. Rev. Asoc. Geol. Argentina, 44: 328-335.

Rabassa, J.O., C. Heusser and R. Stuckenrath. - 1986. New data on Holocene sea transgression in the Beagle Channel: Tierra del Fuego, Argentina. In: J. Rabassa and M. Salemme (eds.): Quaternary of South America and Antarctic Peninsula, 4: 291-309. Balkema, Rotterdam.

Rabassa, J.O., C.J. Heusser and N. Rutter. - 1989. Late-Glacial and Holocene of Argentine Tierra del Fuego. In: J. Rabassa and M. Salemme (eds): Quaternary of South America and Antarctic Peninsula, 7: 327-351. Balkema, Rotterdam.

Urban, H.-J. - 1994. Adaptations of six infaunal bivalve species of Chile: coexistence resulting from differences in morphology, burrowing depth and substrate preferences. Arch. Fish. Mar. Res., 42 (2): 183-195.

Valladares, C. and S. Andrade. - 1990. Estado actual de los bancos naturales de ostiones en los fiordos Brookes y Silva Palma, Estrecho de Magallanes. Inf. Univ. de Magallanes, pp. 1-23 (unpubl. rep.). 